Article

\title{
Investigation of 1-Methylcytosine as a Ligand in Gold(III) Complexes: Synthesis and Protein Interactions
}

\author{
James Beaton and Nicholas P. Farrell * (D) \\ Department of Chemistry, Virginia Commonwealth University, Richmond, VA 23284-2006, USA; \\ beatonjf@vcu.edu \\ * Correspondence: npfarrell@vcu.edu; Tel.: +1-804-828-6320
}

Received: 5 November 2018; Accepted: 15 December 2018; Published: 20 December 2018

\begin{abstract}
The HIV nucleocapsid protein NCp7 was previously shown to play a number of roles in the viral life cycle and was previously identified as a potential target for small molecule intervention. In this work, the synthesis of the previously unreported complexes $[\mathrm{Au}(\text { dien })(1 \mathrm{MeCyt})]^{3+},[\mathrm{Au}(\mathrm{N} \text {-Medien })(1 \mathrm{MeCyt})]^{3+}$, and $[\mathrm{Au}(\text { dien })(\mathrm{Cyt})]^{3+}$ is detailed, and the interactions of these complexes with the models for $\mathrm{NCp} 7$ are described. The affinity for these complexes with the target interaction site, the "essential" tryptophan of the C-terminal zinc finger motif of NCp7, was investigated through the use of a fluorescence quenching assay and by ${ }^{1} \mathrm{H}-\mathrm{NMR}$ spectroscopy. The association of $[\mathrm{Au}(\mathrm{dien})(1 \mathrm{MeC} \mathrm{t})]^{3+}$ as determined through fluorescence quenching is intermediate between the previously reported DMAP and 9-EtGua analogs, while the associations of $[\mathrm{Au}(\mathrm{N} \text {-Medien })(1 \mathrm{MeCyt})]^{3+}$ and $[\mathrm{Au}(\mathrm{dien})(\mathrm{Cyt})]^{3+}$ are lower than the previously reported complexes. Additionally, NMR investigation shows that the self-association of relevant compounds is negligible. The specifics of the interaction with the C-terminal zinc finger were investigated by circular dichroism spectroscopy and electrospray-ionization mass spectrometry. The interaction is complete nearly immediately upon mixing, and the formation of $\mathrm{Au}_{x} \mathrm{~F}^{n+}(x=1$, 2, or 4; F = apopeptide) concomitant with the loss of all ligands is observed. Additionally, oxidized dimerized peptide was observed for the first time as a product, indicating a reaction via a charge transfer mechanism.
\end{abstract}

Keywords: gold; zinc finger proteins; 1-methylcytosine; gold fingers; fluorescence quenching; $\pi-\pi$ stacking; protein-DNA recognition

\section{Introduction}

Gold compounds have a long history in medicinal chemistry. The thiophilic nature of gold suggests sulfur-rich proteins, such as thioredoxin, as reasonable cellular targets for gold action [1]. $\mathrm{Au}(\mathrm{III})$ is quite labile in its chemistry and is susceptible to reduction to $\mathrm{Au}(\mathrm{I})$ [1]. Apart from the inherent difficulty in understanding speciation of an $\mathrm{Au}(\mathrm{III})$ complex in a biological medium, nonselective interactions are also highly likely. This is especially true when highly nucleophilic sulfur sites in proteins are considered as viable targets. Formally, substitution-inert coordination spheres, such as $\mathrm{MN}_{4}$ or $\mathrm{MN}_{3} \mathrm{~L}$ (where $\mathrm{M}=\mathrm{Pt}, \mathrm{Au}$ and $\mathrm{N}_{4}$ may be an $\mathrm{N}_{3}$ chelate such as diethylenetriamine (dien) and $L$ a purine or pyrimidine ligand), have been explored by our group for greater specificity with biomolecules [2]. In principle, we suggested that highly nucleophilic cysteines of biomolecules can be targeted using weak nucleophiles, such as platinum-nucleobase $\mathrm{PtN}_{4}$ complexes for selective peptide reactions [2]. Although $\mathrm{Au}(\mathrm{III})$ is more chemically reactive than $\mathrm{Pt}(\mathrm{II})$, the same principle applies [3]. A complementary approach to enhance selectivity in metal ion-biomolecule interactions involves using 
an inherent property of the protein along with appropriate design of the small molecule. A two-stage approach to selectivity can then be envisaged: Molecular recognition followed by "fixation", where the inorganic moiety forms covalent linkages to the protein of interest. In this contribution, we summarize how this approach might work using formally substitution-inert platinum-metal nucleobase complexes and a tryptophan-containing zinc finger peptide from the HIV nucleocapsid protein HIVNCp7. Specifically, we describe the synthesis and properties of $\mathrm{Au}(\mathrm{III})-1-\mathrm{MeC}$ tosine complexes and their interactions with the C-terminal NCp7-F2 targeting the essential tryptophan of the protein.

Zinc binding proteins are one of the most common types of metalloprotein and make up as much as $10 \%$ of proteins found in humans [4]. In these proteins, zinc can serve a catalytic role, a structural role, and even a recently discovered inhibitory role [5,6]. In zinc-finger proteins, the zinc serves a structural role, binding in a tetrahedral geometry to four surrounding amino acids [7]. These amino acids are generally a combination of cysteines and histidines, and take the forms $\mathrm{Cys}_{2} \mathrm{His}_{2}, \mathrm{Cys}_{2} \mathrm{HiSCys}$ ( $\left.\mathrm{Cys}_{3} \mathrm{His}\right)$, or $\mathrm{Cys}_{4}$. The modification of the zinc-coordinating residues can have a dramatic effect on protein function [8]. The HIV nucleocapsid protein (NCp7), a 55 amino acid protein that contains two $\mathrm{Cys}_{3}$ His zinc fingers (Figure 1), has been identified as a potential target for chemical intervention through the modification of these structural elements. It was previously shown that alteration of the zinc coordination sphere significantly hinders viral replication [5]. NCp7 interacts with its polynucleotide substrate, viral RNA, through guanine stacking with both W37 on the second C-terminal zinc finger motif, as well as through the phenylalanine (F16) located on the first zinc finger $[5,9]$.

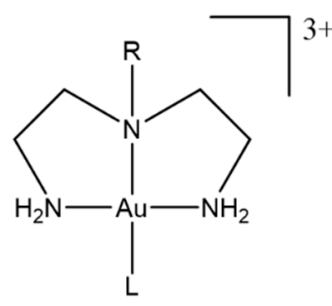

A - L: 1-Methylcytosine, $\mathrm{R}: \mathrm{H}$ B - L: 1-Methylcytosine, $\mathrm{R}: \mathrm{CH}_{3}$ C-L: Cytosine, R: $\mathrm{H}$

$[\text { Au(dien)(DMAP) }]^{3+}-$ L: 4-Dimethylaminopyridine, $R: H$ [Au(dien)(9-EtGua)] ${ }^{3+}-$ L: 9-Ethylguanine, R: H<smiles>Cn1ccc(N)nc1=O</smiles>
1-MeCyt<smiles>CN(C)c1ccncc1</smiles><smiles>CCOCCn1cnc2c(=O)[nH]c(N)nc21</smiles><smiles>CC(=O)N[C@@H](Cc1c[nH]c2ccccc12)C(=O)O</smiles>

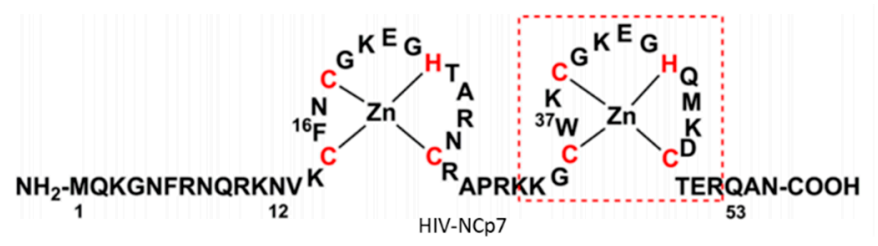

Figure 1. Structures of the complexes studied. Metal binding sites are highlighted in red.

NCp7 recognition by small molecules can be optimized through a noncovalent $\pi-\pi$ stacking interaction between the "essential" tryptophan residue and metallated nucleobases, analogous to the RNA(DNA) interaction. Previously reported gold (III) complexes based on [Au(dien)L] ${ }^{3+}$ (dien = diethylenetriamine; $\mathrm{L}=\mathrm{N}$-heterocycle) were investigated for their ability to stabilize the $\mathrm{Au}(\mathrm{III})$ oxidation state, as well as their ability to eject zinc from zinc-finger proteins [10-13]. In the case of coordination complexes, this interaction brings the metal center in close contact with the highly nucleophilic zinc-bound cysteine residues, allowing for a secondary electrophilic attack by the metal center, resulting in zinc ejection $[2,10]$. Changing the $N$-heterocyclic ligand can be used to fine-tune the electronic properties of the metal center in order to impart higher selectivity for the protein of interest. To this end, the $[\mathrm{Au}(\text { dien }) \mathrm{L}]^{3+}$ coordination sphere was studied with the previously uninvestigated ligand 1-methylcytosine (1-MeCyt). Compared to the $N$-heterocycles 4-Dimethylaminopyridine (DMAP) and 9-Etylguanine (9-EtGua), the free ligand 1-MeCyt has a higher association constant with tryptophan [14]. Additionally, 1-MeCyt has an intermediate basicity (pKa 
$=4.45)$ relative to DMAP $\left(\mathrm{pK}_{\mathrm{a}}=9.1\right)$ and 9-EtGua $\left(\mathrm{pK}_{\mathrm{a}(\mathrm{N} 7)}=2.7\right)$ [15]. Previously, basicity of the heterocycle was thought to be proportional to association constant in the $\left[\mathrm{Au}(\mathrm{dien})(\mathrm{N} \text {-heterocycle) }]^{3+}\right.$ motif [10]. The $[\mathrm{Au}(\mathrm{dien})(1-\mathrm{MeCyt})]^{3+}$ is, to our knowledge, the first 1-MeCytosine compound of $\mathrm{Au}(\mathrm{III})$ to be synthesized, and it completes the series of $\mathrm{Pt}(\mathrm{II})$ and $\mathrm{Pd}(\mathrm{II})$ complexes $\left[\mathrm{M}(\text { dien) } \mathrm{L}]^{n+}(\mathrm{L}=\right.$ 9-EtGua, 1-MeCyt) studied for their isostructural and isoelectronic similarities [14,16,17]. We report the synthesis of the $[\mathrm{Au}(\text { dien })(1-\mathrm{MeCyt})]^{3+}(\mathbf{A}),[\mathrm{Au}(\mathrm{N} \text {-Medien })(1-\mathrm{MeCyt})]^{3+}(\mathbf{B})$, and $[\mathrm{Au}(\mathrm{dien})(\mathrm{Cyt})]^{3+}$ (C) (Figure 1). The associative interaction with $\mathrm{N}$-Acetyl-L-tryptophan (NAcTrp) as a model for the recognition site of NCp7 (W37) was probed through the use of a fluorescence quenching assay. Additionally, the interactions with the C-terminal zinc finger of NCp7 (Figure 1) were investigated by mass spectrometry and circular dichroism spectroscopy.

\section{Results}

\subsection{Synthesis and Characterization}

The previously unreported complexes A, B, and C (Figure 1) were successfully synthesized in accordance with previously published methods [10]. The ${ }^{1} \mathrm{H}-\mathrm{NMR}$ spectra of the complexes $\mathbf{A}$ and $\mathbf{B}$ show multiple protonation states with varying $\mathrm{pH}^{*}$ (Figure S1, see Supplementary Materials), analogous to previously reported 9-EtGua analogs [10]. As 1-MeCyt does not have a labile proton, the changes in the shifts observed with changing $\mathrm{pH}$ may be due to the previously reported deprotonation of the dien-chelate, likely at the central nitrogen in the case of $\mathbf{A}$, and at the terminal nitrogen in the case of $\mathbf{B}\left(\mathrm{pK}_{\mathrm{a}}=3.3\right.$ for 9-EtGua analog) [10]. By analogy with the $\mathrm{Pd}$ and $\mathrm{Pt}$ complexes, [14], the N3 is assigned as the binding site to $\mathrm{Au}(\mathrm{III})$. Unique to the 1-MeCyt complexes, the signals for the aromatic H6 protons split. This splitting of the aromatic protons is not observed in the complex of $\mathbf{C}$ nor in the platinated analog, and highlights the increased electronegativity of $\mathrm{Au}(\mathrm{III})$ relative to $\mathrm{Pt}(\mathrm{II})[3,17]$.

The mass spectra of $\mathbf{A}$ and $\mathbf{B}$ are typical of many coordination complexes because the parent ion peak is nearly indistinguishable from the background. However, the Au(III)-diethylenetriamine backbone bound to fragments of 1-MeCyt is observed, indicating that the desired product had been obtained (Figure S2). Synthesis of the ribosylated analog of $[\mathrm{Au}(\mathrm{Dien})(\mathrm{Cyd})]^{3+}(\mathrm{Cyd}=$ cytidine) was attempted, but the recovered yellow product quickly turned purple, indicating the formation of colloidal gold (reduction of the metal center to $\mathrm{Au}(0)$ ).

\subsection{Determination of Tryptophan Affinity by Fluorescence Quenching}

Complexes A, B, and C were titrated into a solution of NAcTrp, and fluorescence quenching was used to determine the affinity (Figure 2 ). The data was found to be statistically significant ( $p$-values = $4 \times 10^{-4}, 5 \times 10^{-5}$, and $9 \times 10^{-10}$ for $\mathbf{A}, \mathbf{B}$, and $\mathbf{C}$, respectively). Complex $\mathbf{B}$ shows a lower affinity for NAcTrp $\left(K_{a}=13.0 \times 10^{3} \mathrm{M}^{-1}\right)$ than the DMAP and 9-EtGua analogs. The association constant for $\mathbf{A}$, as determined by tryptophan quenching $\left(24.2 \times 10^{3} \mathrm{M}^{-1}\right)$, is intermediate between that of the DMAP and 9-EtGua analogs, while $C$ has a lower association constant $\left(9.31 \times 10^{3} \mathrm{M}^{-1}\right)$. The synthesis and study completes the isoelectronic and isostructural series $[\mathrm{M}(\text { dien }) \mathrm{L}]^{n+}$, where $\mathrm{M}=\mathrm{Pd}(\mathrm{II}), \mathrm{Pt}(\mathrm{II})$, and $\mathrm{Au}(\mathrm{III})$, and $\mathrm{L}=$ purine, 9-Ethylguanine, or pyrimidine, 1-meCytosine $[10,17]$. Figure 2 shows how, for this closely related series, the electronic factors from individual metal ions can be modulated to control the tryptophan affinity to some extent [14]. 


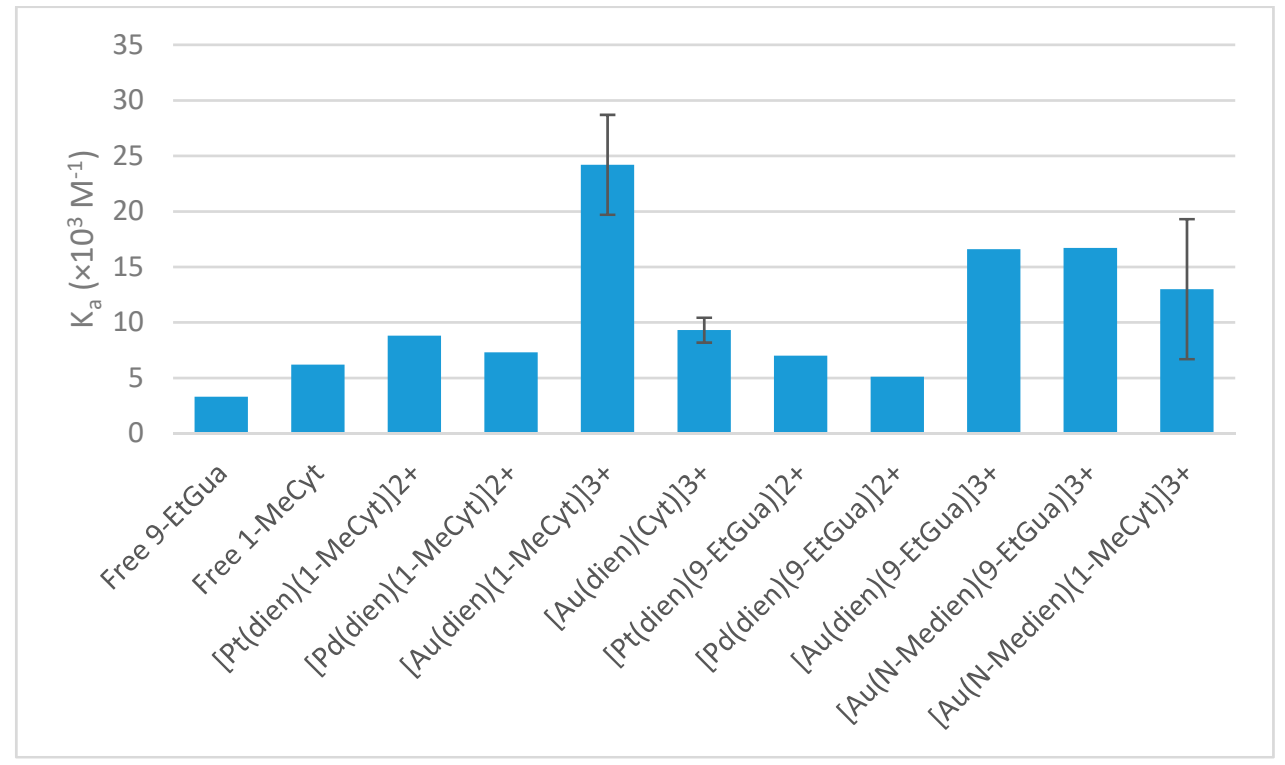

Figure 2. Association constants for $\left[\mathrm{M}(\text { dien)(nucleobase) }]^{n+}\right.$ determined by fluorescence quenching of NAcTrp $[10,16,17]$.

\subsection{Interactions With Zinc Finger Proteins}

Circular dichroism (CD) can be used to gain qualitative information about the structure of the zinc-finger protein. As previously described, the zinc-finger structural motif, shown in the second finger of HIV-NCp7, has a characteristic positive band at $220 \mathrm{~nm}$ and a negative band at 195-200 nm [18]. The CD spectrum of the C-terminal zinc-finger motif of NCp7 (NCp7-F2) was recorded before and after incubation with one equivalent of $\mathbf{A}$, and the interaction was monitored for $4 \mathrm{~h}$ (Figure 3).

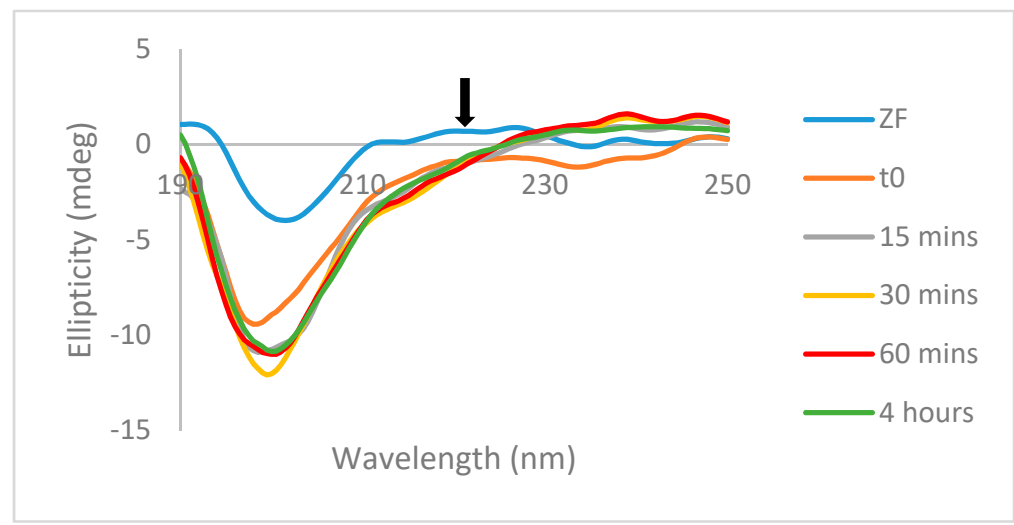

Figure 3. Circular dichroism (CD) spectrum of a 1:1 mixture of the C-terminal zinc-finger of NCp7 and A, monitored over $4 \mathrm{~h}$. The characteristic positive band is indicated by an arrow.

Similarly to all previously studied gold(III)-dien complexes, the interaction with A results in rapid zinc ejection. The decrease seen in the positive band at $220 \mathrm{~nm}$ and the increase seen in the negative band at $200 \mathrm{~nm}$ upon interaction are indicative of random coil, and are similar to the previously reported CD spectrum of the apopeptide [11]. Thus, it is assumed that the zinc was ejected very rapidly. Additionally, the spectrum does not change over the remainder of the next $4 \mathrm{~h}$, indicating that the reaction is complete after $15 \mathrm{~min}$. After a $15 \mathrm{~min}$ incubation with $\mathbf{B}$, the result was also zinc ejection (data not shown).

The mass spectra of a 1:1 mixture of NCp7-F2 and A were recorded immediately after mixing, after $6 \mathrm{~h}$, and after $24 \mathrm{~h}$ (Figure 4a, Figures S3 and S4). The spectra did not change substantially 
from the initial timepoint to the final measurement, supporting the results obtained in the CD spectra and in the previous literature that the interaction between $\mathrm{Au}(\mathrm{III})$ complexes and zinc-finger peptides occurs rapidly. At the time of the initial measurement, the zinc-coordinated peptide is not observed. Additionally, all Au-bound ligands are lost, and only the well-described "gold fingers" are observed [11]. Replacement of zinc by one, two, and four atoms of gold was observed: $605.4805 \mathrm{~m} / \mathrm{z}$ $(4+), 438.1595 \mathrm{~m} / z(6+)$, and $1003.2671 \mathrm{~m} / \mathrm{z}(3+)$, respectively. This is the first instance that incorporation of four gold atoms has been observed upon interaction with a single zinc-finger motif. Oxidized apopeptide (without zinc) is the most readily observable species: $741.3176 \mathrm{~m} / \mathrm{z}(3+)$ and $1111.4739 \mathrm{~m} / \mathrm{z}$ $(2+)$. An unusual feature, previously unseen in our studies, is the presence of oxidized dimerized apopeptide assigned to the mass observed at $889.5802 \mathrm{~m} / \mathrm{z}$ for the $n=5$ charge state.
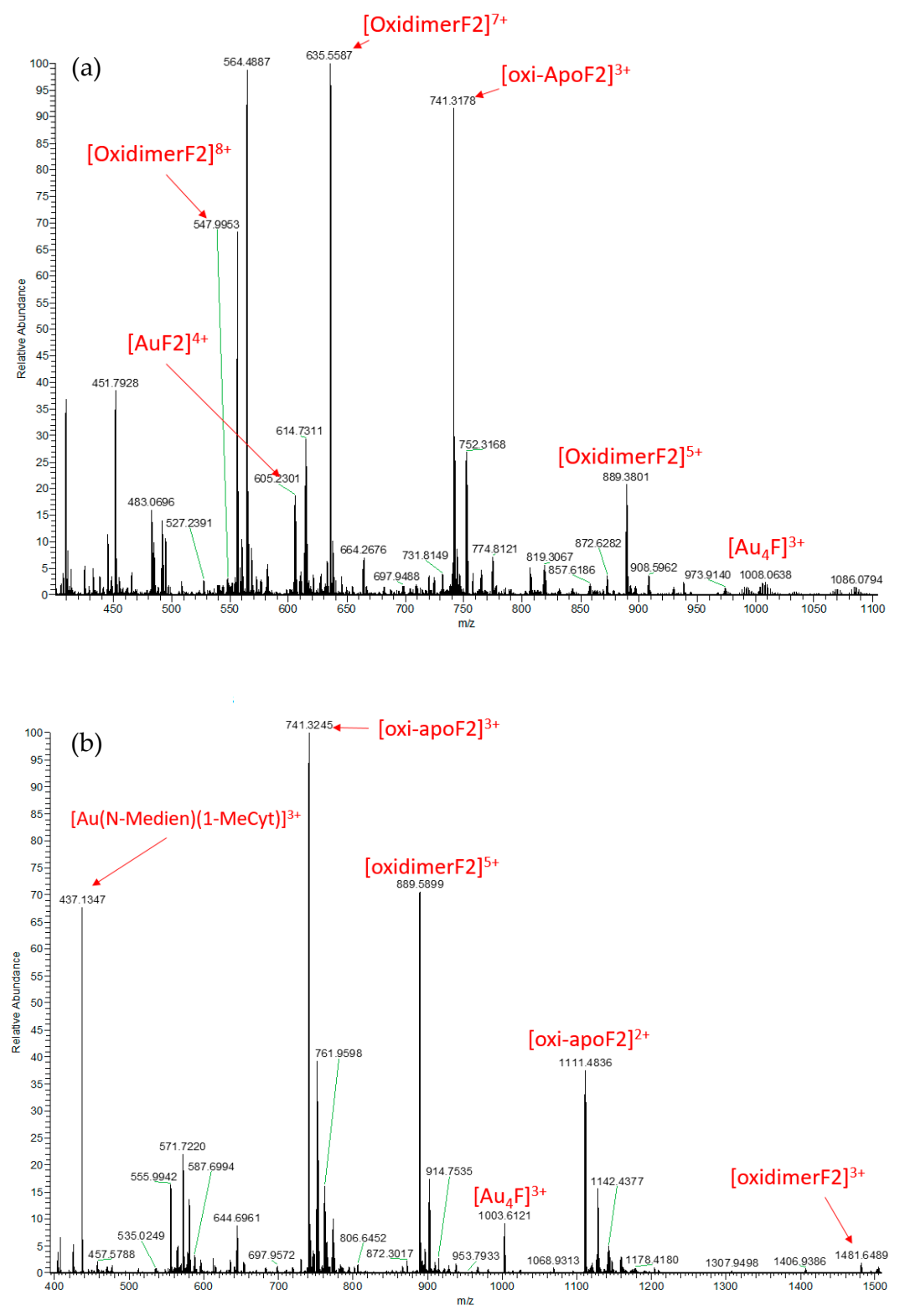

Figure 4. Mass spectra of a 1:1 mixture of $\mathbf{A}(\mathbf{a})$ and $\mathbf{B}(\mathbf{b})$ with the C-terminal zinc-finger of NCp7.

The mass spectra of a 1:1 mixture of NCp7-F2 and B taken immediately upon mixing and after one hour of incubation show essentially the same products as the spectra observed upon interaction with A (Figure 4b, Figure S5). Additionally, there is little difference in the initial spectrum and spectra obtained at later time points, again indicating that the reaction between NCp7-F2 and $\mathbf{B}$ is very rapid. 
Oxidized peptide and oxidized dimerized peptide were seen again, as well as the incorporation of one, two, and four gold ions. Generally, since the ligands are not observed attached to gold after interaction with zinc-finger proteins, the species observed in the mass spectra of the reaction with $\mathbf{A}$ and $\mathbf{B}$ are identical.

\subsection{Cyclic Voltammetry}

Cyclic voltammetry (CV) studies of complexes A and B showed that the new complexes follow the trend of resistance toward reduction, seen in the previously studied DMAP and 9-EtGua analogs (Table 1) [10]. The reduction is irreversible in both complexes, and no other redox events were observed. The reduction potentials were determined relative to $[\mathrm{AuCl}(\text { dien })]^{2+}$. The reduction potential of $\mathbf{A}$ is intermediate between the previously studied DMAP and 9-EtGua analogs, and the Au(III) oxidation state is stabilized relative to the $\mathrm{AuClN}_{3}$ coordination sphere. The reduction potential of $\mathbf{B}$ is slightly higher than the previously studied DMAP analog, but is still slightly lower than the chloride analog.

Table 1. Peak potential values (vs $\mathrm{Ag} / \mathrm{AgCl}$ ) for the reduction of selected $\mathrm{Au}(\mathrm{III})$ complexes at a platinum disc electrode relative to $[\mathrm{AuCl}(\text { dien })]^{2+}$. Measurements were obtained in $50 \mathrm{mM}$ phosphate buffer $(4 \mathrm{mM} \mathrm{NaCl}, \mathrm{pH}=7.4)$.

\begin{tabular}{ccc}
\hline Complex & $\Delta \boldsymbol{E}_{\mathbf{p}}(\mathbf{V})$ & Ref. \\
\hline$[\mathrm{Au}(\text { dien })(9-E t G u a)]^{3+}$ & -0.069 & {$[10]$} \\
{$[\mathrm{Au}(\text { dien })(1-M e C y t)]^{3+}(\mathbf{A})$} & -0.052 & - \\
{$[\mathrm{Au}(\text { dien })(\mathrm{DMAP})]^{3+}$} & -0.048 & {$[10]$} \\
{$[\mathrm{AuCl}(\mathrm{N}-\mathrm{Medien})]^{2+}$} & +0.048 & {$[10]$} \\
{$[\mathrm{Au}(\mathrm{N}-\mathrm{Medien})(1-M e C y t)]^{3+}(\mathbf{B})$} & +0.045 & - \\
{$[\mathrm{Au}(N-M e d i e n)(\mathrm{DMAP})]^{3+}$} & +0.042 & {$[10]$} \\
{$[\mathrm{Au}(\mathrm{N}-\mathrm{Medien})(9-\mathrm{EtGua})]^{3+}$} & +0.017 & {$[10]$} \\
\hline
\end{tabular}

\section{Discussion}

The synthesis of complexes A and $\mathbf{B}$ serves to complete the series of complexes of the form $[\mathrm{M}(\mathrm{dien})(1-\mathrm{MeCyt})]^{n+}$, in which the $\mathrm{Pt}(\mathrm{II})$ and $\mathrm{Pd}(\mathrm{II})$ complexes, both isoelectronic and isostructural to the $\mathrm{Au}(\mathrm{III})$ complexes investigated in this work, had been previously investigated. However, the $\mathrm{Au}(\mathrm{III})$ analog had remained unreported up to this point.

Tryptophan is present on the C-terminal zinc-finger of NCp7 and plays an essential role in protein-DNA/RNA recognition, which occurs through a $\pi-\pi$ stacking interaction between the aromatic tryptophan (or in the case of the full peptide, phenylalanine) residues and the nucleobases in DNA/RNA $[14,19]$. Previously, it was shown that association with free $N$-Acetyl-L-tryptophan (NAcTrp) is a good indicator of a compound's affinity for the full protein. The fluorescent emission of NAcTrp can be quenched by a complex that interacts with NAcTrp in a $\pi-\pi$ stacking interaction, and the degree to which the fluorescent emission is quenched is directly related to the strength of the interaction $[3,10-12,14,15]$.

Compared to the $\mathrm{Pt}(\mathrm{II})$ and $\mathrm{Pd}(\mathrm{II})$ analogs, the $\mathrm{Au}(\mathrm{III})$ complexes show a higher affinity for NAcTrp, consistent with the previous literature $[5,20]$. The lower affinity of $\mathbf{B}$ for NAcTrp than the DMAP analog and similar affinity compared to the 9-EtGua analog is surprising given the intermediate basicity of 1-MeCyt. The result for A is as expected, as the basicity of free 1-MeCyt is intermediate between that of DMAP and 9-EtGua, but the results obtained for $\mathbf{B}$ and $\mathbf{C}$ show that there are factors other than the basicity that influence the associative interaction. Therefore, it is likely that the $N$-methyl group present on the chelating ligand in B causes a lower association constant for the $\pi-\pi$ stacking interaction with NAcTrp than in A. This shows that the modulation of the electronic environment of the metal center can influence the interactions between the complex and the protein recognition element. However, this reduction upon methylation of the chelating ligand is only observed to a lesser extent in the 9-EtGua analog. 
Mass spectrometry studies with the previously reported $A u(I I I)$ analogs showed that the formation of random coil observed by CD was accompanied by the formation of "gold fingers," in which one or more atoms of gold replaced the zinc in the zinc-finger structure upon zinc ejection [10]. The observation of oxidized apopeptide is indicative of disulfide bond formation between cysteine molecules of the same peptide, while the observation of oxidized dimerized apopeptide is indicative of disulfide bond formation between cysteine residues of different protein molecules. These interactions would likely be facilitated by the reduction of the metal center from $\mathrm{Au}$ (III) to $\mathrm{Au}(\mathrm{I}) / \mathrm{Au}(0)$. This interaction is in contrast to the interactions observed in the Pt(II) analogs, in which reduction and incorporation of the Pt(II) metal center is not seen. Instead, the metal center is observed with the ligands intact and with the zinc still incorporated $[3,5,20]$. Like previously reported aurated DMAP and 9-EtGua analogs, but unlike the platinated analogs, peaks representing the unreacted zinc-finger protein are not seen at the initial time point, highlighting the increased reactivity of the $\mathrm{Au}(\mathrm{III})$ metal center. The incorporation of four equivalents of gold was thought to be due to a difference in the redox properties of $\mathbf{A}$ and $\mathbf{B}$ when compared to the previously studied $\mathrm{Au}(\mathrm{III})$ analogs. Therefore, CV studies were carried out in order to assess these differences.

$\mathrm{CV}$ showed that it is significantly easier to reduce cytosine and thymine than it is to reduce adenine and guanine [21]. In the context of interaction with zinc-finger peptides, this reduction would be accompanied by disulfide bond formation. In this case, the greater ease of reduction may cause the occurrence of a charge transfer mechanism, in which the disulfide bond formation occurs across two equivalents of the peptide, forming the oxidized dimerized peptide uniquely observed in the case of $\mathbf{A}$ and $\mathbf{B}$, in contrast to the simple oxidation of one equivalent of zinc finger. Whereas this latter oxidation is easily understood with reduction of $\mathrm{Au}(\mathrm{III})$ to $\mathrm{Au}(\mathrm{I})$ and concomitant oxidation of two Zn-bound cysteines, the first step in peptide dimerization may be an electron transfer between the 1-MeCyt ligand to the tryptophan ligand. This suggestion would explain why similar products would not be seen in the isostructural $\mathrm{Pt}(\mathrm{II})$ complexes, as the platinum center is not reduced upon interaction with zinc-finger peptides, while a charge transfer mechanism must occur with concomitant reduction of the metal center [22]. No evidence for self-association was observed by NMR studies for A or for free ligands (Figure S6). Previously published work discussed the reduction potential and accessibility of the cysteine residues of the C-terminal zinc finger, and this data suggests that disulfide bond formation would likely occur between C39 residues (Figure 5), as C39 has a reduction potential nearly as low as that of $C 49(-33.35$ vs. $-35.91 \mathrm{mV})$ but has a much greater accessibility ( $52.88 \mathrm{vs}$. 15.17) [22]. It is also possible that reduction of multiple molecules of $\mathbf{A}$ or $\mathbf{B}$ could also result in the formation of multiple disulfide bonds, in which case both C49 and C39 could form disulfide bonds to form the dimer.

\section{KGCWKÇGKEGHQMKDCTER KGCWKCGKEGHQMKDCTER}

Figure 5. Illustration of disulfide bond formation. Zinc coordinating residues are highlighted in red.

\section{Materials and Methods}

[ $\mathrm{AuCl}($ dien $)] \mathrm{Cl}_{2}$ and $\left[\mathrm{AuCl}(\mathrm{N}\right.$-Medien) $] \mathrm{Cl}_{2}$ were synthesized according to previously published procedures [23]. The 1-methylcytosine was synthesized and purified according to previously published procedures $[24,25]$. The addition of the $N$-heterocycles were carried out analogously to previously published procedures [10]. The apoNCp7-F2 was purchased from GenScript (Piscataway, NJ, USA). NCp7-F2 was prepared according to previously published procedures [10]. All nuclear magnetic resonance (NMR) studies were carried out in deuterium oxide on a Bruker AVANCE III (400 MHz) (Bruker, Billerica, MA, USA). CD studies were carried out at $50 \mu \mathrm{M}$ concentrations in water on a Jasco J-1500 spectrometer (Jasco, Easton, MD, USA). Mass spectrometry studies were carried out on a 
Thermo Electron Corporation Orbitrap Velos mass spectrometer (Thermo Scientific, Waltham, MA, USA). Mass spectrometry samples were prepared at $10 \mu \mathrm{M}$ concentrations in $10 \%$ methanol, and were sprayed at $2.30 \mathrm{kV}$ and $0.9 \mu \mathrm{L} /$ minute at $230{ }^{\circ} \mathrm{C}$.

Synthesis of $[\mathrm{Au}($ dien $)(1-\mathrm{Mecyt})]\left(\mathrm{NO}_{3}\right)_{3}(\mathrm{~A}):[\mathrm{AuCl}($ dien $)] \mathrm{Cl}_{2}(101.2 \mathrm{mg}, 0.249 \mathrm{mmol})$ was dissolved in $\mathrm{dH}_{2} \mathrm{O}(10 \mathrm{~mL})$. The 1-methylcytosine $(30.2 \mathrm{mg}, 0.242 \mathrm{mmol})$ and silver nitrate $(125.4 \mathrm{mg}$, $0.738 \mathrm{mmol}$ ) were added, and the reaction mixture was stirred under light protection for $72 \mathrm{~h}$. The precipitated silver chloride was removed by filtration through celite, and the filtrate was evaporated to dryness under reduced pressure. The orange/yellow residue was dissolved in a small amount of $\mathrm{dH}_{2} \mathrm{O}$, and acetone was added to the cloud point. The orange/yellow solid product was collected by vacuum filtration and characterized by ${ }^{1} \mathrm{H}-\mathrm{NMR}$, infrared spectroscopy, and elemental analysis (experimental (theoretical)): C: $14.46(14.62) \mathrm{H}: 2.81(2.86) \mathrm{N}: 17.70(17.17) .{ }^{1} \mathrm{H}$ NMR $\left(\mathrm{D}_{2} \mathrm{O}\right.$, $400 \mathrm{MHz}): 7.83,7.73(\mathrm{~d}, 1 \mathrm{H}), 6.14(\mathrm{~d}, 1 \mathrm{H}), 3.69$ (broad, 6H), 3.45 (s, 3H), 3.18 (broad, 2H). UV-Vis (1 mM, $\left.\mathrm{H}_{2} \mathrm{O}\right): 237 \mathrm{~nm}(\mathrm{Abs}=3.98), 357 \mathrm{~nm}(\mathrm{Abs}=0.408)$.

Synthesis of $[\mathrm{Au}(\mathrm{N}-\mathrm{Medien})(1-\mathrm{MeCyt})]\left(\mathrm{NO}_{3}\right)_{3}(\mathbf{B}):[\mathrm{AuCl}(\mathrm{N}-\mathrm{MeDien})] \mathrm{Cl}_{2}(100.12 \mathrm{mg}, 0.238 \mathrm{mmol})$ was dissolved in $\mathrm{dH}_{2} \mathrm{O}(10 \mathrm{~mL})$. Silver nitrate $(121.4 \mathrm{mg}, 0.715 \mathrm{mmol})$ and 1-methylcytosine $(29.8 \mathrm{mg}$, $0.238 \mathrm{mmol}$ ) were added and the reaction mixture was stirred under light protection for 4 days. The reaction mixture was filtered through celite and the solvent was evaporated under reduced pressure. The resulting crude product was dissolved in a small amount of water and excess acetone was added to precipitate the yellow product, characterized by ${ }^{1} \mathrm{H}-\mathrm{NMR}$, Far-IR, and elemental analysis (experimental (theoretical)): C: $16.77(17.20) \mathrm{H}: 3.33(3.46) \mathrm{N}: 17.69(18.05) .{ }^{1} \mathrm{H}-\mathrm{NMR}\left(\mathrm{D}_{2} \mathrm{O}, 400 \mathrm{MHz}\right)$ : 7.82, $7.72(\mathrm{~d}, 1 \mathrm{H}), 6.13(\mathrm{~d}, 1 \mathrm{H}), 4.21,4.09(\mathrm{~m}, 4 \mathrm{H}), 3.65(\mathrm{~m}, 3 \mathrm{H}), 3.46(\mathrm{~d}, 2 \mathrm{H}), 3.38(\mathrm{~s}, 3 \mathrm{H}), 3.19(\mathrm{~m}, 2 \mathrm{H})$. UV-Vis $\left(1 \mathrm{mM}, \mathrm{H}_{2} \mathrm{O}\right): 237 \mathrm{~nm}(\mathrm{Abs}=3.94), 352 \mathrm{~nm}(\mathrm{Abs}=0.921)$.

Synthesis of $[\mathrm{Au}($ dien $)(\mathrm{Cyt})]\left(\mathrm{NO}_{3}\right)_{3}(\mathrm{C}):[\mathrm{AuCl}($ dien $)] \mathrm{Cl}_{2}(100.44 \mathrm{mg}, 0.168 \mathrm{mmol})$ was dissolved in $\mathrm{dH}_{2} \mathrm{O}(10 \mathrm{~mL})$. Cytosine $(28.2 \mathrm{mg}, 0.164 \mathrm{mmol})$ and silver nitrate $(85.61 \mathrm{mg}, 0.506 \mathrm{mmol})$ were added, and the reaction mixture was stirred under light protection overnight. The precipitated silver chloride was removed by filtration through celite, and the filtrate was evaporated to dryness under reduced pressure. The orange residue was dissolved in a small amount of $\mathrm{dH}_{2} \mathrm{O}$, and acetone was added to the cloud point. The orange solid product was collected by vacuum filtration. ${ }^{1} \mathrm{H}-\mathrm{NMR}\left(\mathrm{D}_{2} \mathrm{O}, 400 \mathrm{MHz}\right)$ : $7.64(\mathrm{~d}, 1 \mathrm{H}), 6.06(\mathrm{~d}, 1 \mathrm{H}), 3.52(\mathrm{t}, 4 \mathrm{H}), 2.99$ (broad, $4 \mathrm{H})$.

Fluorescence quenching of tryptophan: Tryptophan quenching methods were adapted from those previously published [10]. A solution of $N$-acetyl-L-tryptophan $(5 \mu \mathrm{M})$ was titrated with the $\mathrm{Au}(\mathrm{III})$ complexes $(7.5 \mathrm{mM})$ in amounts ranging from 1-10 equivalents of quencher. The decrease in fluorescence intensity of $\mathrm{N}$-acetyl-L-tryptophan was plotted using the Eadie-Hofstee method in order to determine the association constant.

Determination of self-association by NMR spectroscopy: Varying concentrations $(0.1-2.5 \mathrm{mM})$ of $\mathrm{N}$-heterocycle and gold(III) complex were analyzed by ${ }^{1} \mathrm{H}-\mathrm{NMR}$. The degree of self-association was determined by previously published methods [26]. The change in chemical shift with increasing concentration was fitted to the equation $\delta_{\text {obs }}=\left\{\left[-K_{d}+\left(K_{d}^{2}+8 C K_{d}\right)^{1 / 2}\right] / 4 C\right\}\left(\delta_{M}-\delta_{D}\right)+\delta_{D}$. Microsoft Excel Solver was used to solve the three-variable equation.

Cyclic voltammetry: CV studies were carried out following the previously published procedures [10]. A three-electrode cell was employed, containing a platinum disk working electrode, a platinum mesh counter electrode, and a silver/silver chloride reference electrode $(0.1 \mathrm{M} \mathrm{KCl})$. Solutions were degassed with nitrogen for 15 minutes before analysis. Measurements were obtained in $50 \mathrm{mM}$ phosphate buffer $(4 \mathrm{mM} \mathrm{NaCl}, \mathrm{pH}=7.4)$.

\section{Conclusions}

In conclusion, the previously unreported 1-methylcytosine complexes based on the [Au(dien) $(\mathrm{N} \text {-heterocycle) }]^{3+}$ motif, $\mathbf{A}$, and $\mathbf{B}$, have been synthesized and investigated for their ability to interact with the C-terminal finger of the HIV nucleocapsid protein NCp7 as a model for a protein with highly nucleophilic cysteines. Gold compounds are considered to primarily interfere with protein, 
rather than DNA, function. In considering the series $[\mathrm{M}(\text { dien }) \mathrm{L}]^{n+}$, the electronic properties can be modulated systematically for optimal protein interaction. A key feature leading to the rational design of complexes of the form $[\mathrm{Au}(\mathrm{dien}) \mathrm{L}]^{3+}$ is the enhancement of the redox stability of the complexes relative to the precursor $[\mathrm{AuCl}(\mathrm{dien})]^{2+}$, due to the incorporation of a more substitution inert nitrogen donor in the form of an $\mathrm{N}$-heterocycle [9]. In the case of the more sterically hindered complex $\mathbf{B}$, the reduction potential is greater than the chloride analog $[\mathrm{AuCl}(\mathrm{N} \text {-Medien })]^{2+}$, and is in line with the reduction in stabilization of the gold(III) oxidation state seen in the complex [Au(N-Medien)(DMAP) ${ }^{3+}$. The aurated nucleobase may interact preferentially with an RNA(DNA) recognition motif, such as tryptophan. Formation of oxidized dimerized peptide was observed in the mass spectrometry studies conducted with NCp7-F2, and indicated a difference in the reactivity profile of $\mathbf{A}$ and $\mathbf{B}$ compared to the previously studied DMAP and 9-EtGua analogs. These results further confirm that tuning the electronic and steric properties of the ligands on the $\mathrm{Au}(\mathrm{III})$ coordination sphere can modulate the strength of interaction between complexes of the $\left[\mathrm{Au}(\mathrm{dien})(\mathrm{N} \text {-heterocycle) }]^{3+}\right.$ motif and a zinc finger a systematic manner.

Supplementary Materials: The following are available online at http:/ /www.mdpi.com/2304-6740/7/1/1/s1: Figure S1: The ${ }^{1} \mathrm{H}$-NMR spectra of $\mathbf{A}$ (left) and $\mathbf{B}$ (right) at varying $\mathrm{pH}^{*}$ values, where $\mathrm{pH}^{*}$ is the reading of the $\mathrm{pH}$ meter; Figure S2: Mass spectra of A (left) and B (right); Figure S3: Mass spectrum of A with NCp7-F2 immediately after mixing; Figure S4: Mass spectrum of A with NCp7-F2 6 hours after mixing; Figure S5: Mass spectrum of $\mathbf{B}$ with NCp7-F2 1 hour after mixing; Figure S6: Self-association determination of DMAP, NAcTrp, 9-EtGua, and A.

Author Contributions: Conceptualization: N.P.F. Investigation and draft writing: J.B. Writing, reviewing, and editing: N.P.F.

Funding: This research was funded by National Science Foundation CHE CHE1413189.

Acknowledgments: We gratefully acknowledge Christopher J. Freeman and Maryanne M. Collinson for assistance in carrying out the CV experiments.

Conflicts of Interest: The authors declare no conflict of interest.

\section{References}

1. Berners-Price, S.J.; Filipovska, A. Gold Compounds as Therapeutic Agents for Human Diseases. Metallomics 2011, 3, 863-873. [CrossRef] [PubMed]

2. De Paula, Q.A.; Tsotsoros, S.D.; Qu, Y.; Bayse, C.A.; Farrell, N.P. Platinum-nucleobase PtN4 Complexes as Chemotypes for Selective Peptide Reactions with Biomolecules. Inorg. Chim. Acta 2012, 393, 222-229. [CrossRef]

3. Bernardes, V.H.F.; Qu, Y.; Du, Z.; Beaton, J.; Vargas, M.D.; Farrell, N.P. Interaction of the HIV NCp7 Protein with Platinum(II) and Gold(III) Complexes Containing Tridentate Ligands. Inorg. Chem. 2016, 55, 11396-11407. [CrossRef] [PubMed]

4. Andreini, C.; Banci, L.; Bertini, I.; Rosato, A. Counting the Zinc-Proteins Encoded in the Human Genome. J. Proteome Res. 2006, 5, 196-201. [CrossRef] [PubMed]

5. Morellet, N.; Jullian, N.; De Rocquigny, H.; Maigret, B.; Darlix, J.; Roques, B.P. Determination of the Structure of the Nucleocapsid Protein NCp7 from the Human Immunodeficiency Virus Type 1 by ${ }^{1} \mathrm{H}$ NMR. EMBO J. 1992, 11, 3059-3065. [CrossRef]

6. Daniel, A.G.; Peterson, E.J.; Farrell, N.P. The Bioinorganic Chemistry of Apoptosis: Potential Inhibitory Zinc Binding Sites in Caspase-3. Angew. Chem. 2014, 126, 4182-4185. [CrossRef]

7. Klug, A.; Rhodes, D. Zinc Fingers: A Novel Protein Fold for Nucleic Acid Recognition. Cold Spring Harb. Symp. Quant. Biol. 1987, 52, 473-482. [CrossRef]

8. Krishna, S.S.; Majumdar, I.; Grishin, N.V. Structural Classification of Zinc Fingers. Nucleic Acids Res. 2003, 31, 532-550. [CrossRef]

9. South, T.L.; Blake, P.R.; Sowder, R.C., III; Arthur, L.O.; Henderson, L.E.; Summers, M.F. The Nucleocapsid Protein Isolated from HIV-1 Particles Binds Zinc and Forms Retroviral-Type Zinc Fingers. Biochemistry 1990, 29, 7786-7789. [CrossRef]

10. Spell, S.R.; Farrell, N.P. Synthesis and Properties of the First $\left[\mathrm{Au}(\mathrm{dien})(\mathrm{N} \text {-heterocycle) }]^{3+}\right.$ Compounds. Inorg. Chem. 2014, 53, 30-32. [CrossRef] 
11. Spell, S.R.; Farrell, N.P. [Au(dien)(N-heterocycle) $]^{3+}$ : Reactivity with Biomolecules and Zinc Finger Peptides. Inorg. Chem. 2015, 54, 79-86. [CrossRef] [PubMed]

12. Spell, S.R.; Mangrum, J.B.; Peterson, E.J.; Fabris, D.; Ptak, R.; Farrell, N.P. Au(III) Compounds as HIV Nucleocapsid Protein (NCp7)-Nucleic Acid Antagonists. Chem. Commun. 2017, 53, 91-94. [CrossRef] [PubMed]

13. Anzellotti, A.I.; Farrell, N.P. Zinc Metalloproteins as Medicinal Targets. Chem. Soc. Rev. 2008, 37, 1629-1651. [CrossRef] [PubMed]

14. Anzellotti, A.I.; Bayse, C.A.; Farrell, N.P. Effects of Nucleobase Metalation on Frontier Molecular Orbitals: Potential Implications for $\pi$-Stacking Interactions with Tryptophan. Inorg. Chem. 2008, 47, 10425-10431. [CrossRef]

15. Verdolino, V.; Cammi, R.; Munk, B.H.; Schlegel, H.B. Calculation of $\mathrm{pK}_{\mathrm{a}}$ Values of Nucleobases and Guanine Oxidation Products Guanidinohydantoin and Spiroiminodihydantoin using Density Functional Theory and a Polarizable Continuum Model. J. Phys. Chem. B 2008, 112, 16860-16873. [CrossRef]

16. Anzellotti, A.I.; Ma, E.S.; Farrell, N. Platination of Nucleobases to Enhance Noncovalent Recognition in Protein-DNA/RNA Complexes. Inorg. Chem. 2005, 44, 483-485. [CrossRef]

17. Anzellotti, A.I.; Sabat, M.; Farrell, N. Covalent and Noncovalent Interactions for [Metal(dien)nucleobase] ${ }^{2+}$ Complexes with L-Tryptophan Derivatives: Formation of Palladium-Tryptophan Species by Nucleobase Substitution under Biologically Relevant Conditions. Inorg. Chem. 2006, 45, 1638-1645. [CrossRef]

18. dePaula, Q.A.; Mangrum, J.B.; Farrell, N.P. Zinc Finger Proteins as Templates for Metal Ion Exchange: Substitution Effects on the C-Finger of HIV Nucleocapsid NCp7 Using M(chelate) Species (M = Pt, Pd, Au). J. Inorg. Biochem. 2009, 103, 1347-1354. [CrossRef]

19. Ma, E.S.F.; Daniel, A.G.; Farrell, N.P. Dinuclear Platinum Complexes Containing Planar Aromatic Ligands to Enhance Stacking Interactions with Proteins. ChemMedChem 2014, 9, 1155-1160. [CrossRef]

20. Tsotsoros, S.D.; Lutz, P.B.; Daniel, A.G.; Peterson, E.J.; de Paiva, R.E.F.; Rivera, E.; Qu, Y.; Bayse, C.A.; Farrell, N.P. Enhancement of the Physiochemical Properties of $\left[\mathrm{Pt}(\mathrm{dien})(\text { nucleobase) }]^{2+}\right.$ for HIVNCp7 Targeting. Chem. Sci. 2017, 8, 1269-1281. [CrossRef]

21. Manoj, P.; Mohan, H.; Mittal, J.P.; Manoj, V.M.; Aravindakumar, C.T. Charge Transfer from 2-Aminopurine Radical Cation and Radical Anion to Nucleobases: A Pulse Radiolysis Study. Chem. Phys. 2007, 331, 351-358. [CrossRef]

22. Abbehausen, C.; de Paive, R.E.F.; Bjornsson, R.; Gomes, S.Q.; Du, Z.; Corbi, P.P.; Lima, F.A.; Farrell, N. X-ray Absorption Spectroscopy Combined with Time-Dependent Density Functional Theory Elucidates Differential Substitution Pathways of $\mathrm{Au}(\mathrm{I})$ and $\mathrm{Au}(\mathrm{III})$ with Zinc Fingers. Inorg. Chem. 2018, 57, 218-230. [CrossRef] [PubMed]

23. Nardin, G.; Randaccio, L.; Annibale, G.; Natile, G.; Pitteri, B. Comparison of Structure and Reactivity of bis(2-aminoethyl)amine- and bis(2-aminoethyl)amido-chlorogold(III) Complexes. J. Chem. Soc. Dalton Trans. 1980, 2, 220-223. [CrossRef]

24. Greco, E.; Aliev, A.E.; Lafitte, V.G.H.; Bala, K.; Duncan, D.; Pilon, L.; Golding, P.; Hailes, H.C. Cytosine Modules in Quadruple Hydrogen Bonded Arrays. New J. Chem. 2010, 34, 2634-2642. [CrossRef]

25. Helfer, D.L., II; Hosmane, R.S.; Leonard, N.L. Selective Alkylation and Aralkylation of Cytosine at the 1-Position. J. Org. Chem. 1981, 46, 4803-4804. [CrossRef]

26. Waterhous, D.V.; Muccio, D.D. ${ }^{1} \mathrm{H}$ and ${ }^{13} \mathrm{C}$ Studies on the Self-Association of Retinoic Acid. Magn. Reson. Chem. 1990, 28, 223-226. [CrossRef]

(C) 2018 by the authors. Licensee MDPI, Basel, Switzerland. This article is an open access article distributed under the terms and conditions of the Creative Commons Attribution (CC BY) license (http:/ / creativecommons.org/licenses/by/4.0/). 